\title{
GLUE, THE TRAINSPOTTING NOVELS AND TRANSITION FROM WORKING-CLASS SOLIDARITY TO NEOLIBERAL ENTREPRENEURSHIP
}

Amaury Garcia dos Santos Neto ${ }^{1 *}$

${ }^{1}$ Universidade do Estado do Rio de Janeiro, Rio de Janeiro, RJ, Brasil

\begin{abstract}
This article discusses some of Irvine Welsh's novels considering the period of transition from an industrial to a post-industrial society. We focus on the effects of this shift on fictional characters who originate from the working classes in Edinburgh, as represented in Welsh's Glue (2001) and the Trainspotting Novels. As such works cover the period from the early 1970 's to the late 2010's, Welsh evidences the move from the traditional working-class ethos, typified by Union solidarity, to the neoliberal culture of entrepreneurship and its negative aspects. We discuss how Welsh depicts neoliberal practices either rendering workers redundant for the new circumstances or creating new ways to exploit labour.

Keywords: Irvine Welsh; Transition; Post-industrial World; Workingclass Solidarity; Neoliberal Entrepreneurship
\end{abstract}

\footnotetext{
"Has a Ph.D. in Literature, Culture and Contemporaneity from Pontifícia Universidade Católica do Rio de Janeiro (2015) and is currently at the closing stages of his post-doctoral research on British Literature at Universidade do Estado do Rio de Janeiro. He has researched on different themes and authors within British literature, most notably Anthony Burgess, having written a doctoral thesis on autobiographical aspects of Burgess's novels and published articles on the topic. During his doctorate, he was a visiting researcher at the International Anthony Burgess Foundation in Manchester, England. His present studies are concerned with Irvine Welsh's representations of the Scottish working-class ethos. He teaches English at Colégio Militar do Rio de Janeiro (CMRJ). Email: amaury.garcia@gmail.com ORCID: 0000-0001-6564-2424.
} 


\section{Introduction}

This article discusses the shift from an industrial to a post-industrial society as represented by Irvine Welsh in six of his novels, Glue (2001), Trainspotting (1993), Porno (2002), Skagboys (2012), The Blade Artist (2016) and Dead Men's Trousers (2018). As the novelist himself has said in different interviews, his works deal with the notion of transition, mainly effected by neoliberal policies and the advent of globalisation as well as their consequential transformation of industry in the West.

The criterion used for the selection of works was twofold: (1) they encompass the last five decades of history and (2) they depict how changes in work affect the fictional characters both professionally and personally. Glue tells the story of four friends from the working-class district of Leith, Edinburgh, from the 1970's to the beginning of the new millennium. The other novels, known as the Trainspotting saga, present another group of friends from the same area, with a narrative covering the interval from the 1984-1985 miner's strike to 2016, after the result of the referendum on whether the UK would remain or leave the European Union. As the universe of the Trainspotting saga and Glue overlap, some main characters of an axis appear in the other as minor ones. Therefore, we consider it relevant to read and discuss such works comparatively, as we believe they present different aspects of the same phenomenon, i.e. the period of transition the working classes have been going through from the last decades of the $20^{\text {th }}$ Century.

Welsh focuses mainly on the poor of his native Edinburgh. Nonetheless, while it is true that he problematises notions related to Scotland and its national identity (or even the possibility of a national identity altogether in a globalised world), many of the aspects he addresses are not circumscribed to the experience of his country, but resonate with workers from all around the globe. Thus, we believe discussing Welsh's works is a profitable endeavour for us to understand some of the changes in contemporary society.

We propose to start by contextualising his work historically in the next section. After that, we offer a very brief presentation of the author and his fictional works, mainly focusing on the corpus selected for this article. Following, we approach such corpus, so we can discuss the points risen in this introduction. Finally, we offer our closing remarks.

\section{Historical context}

Irvine Welsh's oeuvre cannot be approached without referring to two historical facts that have deeply influenced his own writing and Scottish literature as a whole at the closing stages of the $20^{\text {th }}$ century. The first is the failed referendum on the devolution of the Scottish Parliament in 1979. The second consists in Margaret Thatcher's rule as Prime Minister of the United Kingdom from 1979 to 1990.

Robert Morace (2007) explains that the feeling of national pride in Scotland gained momentum during the 1960's and 1970's (Irvine Welsh 24). Following the sentiment, the Scotland Act of 1978 proposed a referendum of devolution 
of Parliament to Scotland, which could bring back political power gradually relinquished for almost three centuries. It resulted in devolution, with a narrow margin of 51.6\%. Nevertheless, it failed to meet a requirement Westminster amended: that at least $40 \%$ of all eligible voters favoured the devolution. As the turnout was only $64 \%$, the result was invalidated. Morace argues that the requirement was interpreted as "proof of both English treachery - of London's and therefore England's power over Scotland - and Scottish cowardice, thus provoking intense debates and feelings of self-loathing, national and personal" (Irvine Welsh 24).

To make matters worse, that was the year when Thatcher was elected Prime Minister, starting a period that saw the introduction of neoliberal policies in the UK. Following David Harvey's definition (2007), we understand neoliberalism as:

a theory of political economic practices that proposes that human wellbeing can best be advanced by liberating individual entrepreneurial freedoms and skills within an institutional framework characterized by strong private property rights, free markets and free trade. The role of the state is to create and preserve an institutional framework appropriate to such practices. The state has to guarantee, for example, the quality and integrity of money. It must also set up those military, defence, police, and legal structures and functions required to secure private property rights and to guarantee, by force if need be, the proper functioning of markets. Furthermore, if markets do not exist (...) then they must be created, by state action if necessary. But beyond these tasks the state should not venture. (93-107)

In such instance, freedom of enterprise is closely associated with accumulation of private property. One is only able to invest if one has capital. In other words, the political and economic frameworks required by neoliberalism advance the interests of those who already concentrate wealth, i.e. big private companies that are controlled by the upper classes. Under neoliberal thought, the scales of the economy are, thus, tipped to favour the elites. This is one of the reasons why Harvey argues that, ultimately, neoliberalism might work as a project to restore class power (324).

Following such ideals, Thatcher's policies effected a dramatic shift in Britain, reducing the role of the State in society while fostering private enterprise. As Harvey explains,

[Thatcherism] entailed confronting trade union power, attacking all forms of social solidarity that hindered competitive flexibility (...), dismantling or rolling back the commitments of the welfare state, the privatization of public enterprises (...), reducing taxes, encouraging entrepreneurial initiative, and creating a favourable business climate to induce a strong inflow of foreign investment (...). (414)

As Britain relied heavily on State-sponsored or national companies for its economy, the consequence of such new directions for workers was dire. It could 
not be worse for Scotland, a country economically based on industrial activities. Peter Clarke (2004) points that by "the autumn of 1981 unemployment was 2.8 million, double the level in May 1979; and in the winter of 1982-3 it reached 3.3 million" (372). The regions that suffered the most were traditional industrial areas, such as Scotland, Wales and the north of England (Clarke 372). It comes as no surprise, as Morace states, that Scots "came to feel even more alienated from and oppressed by Britishness" (Irvine Welsh 24).

Thatcher's tenure did not affect the reality of work in Scotland only, but in Britain as a whole. Privatising state services was the order of the day, as many national companies were sold to private enterprises, especially in the fields of telecommunications and transportation. Privatisation "became the most dynamic policy of Thatcher's period in office" (Clarke 381).

One of the worst hit economic activities was mining. Before Thatcher, it employed over a million workers in Britain. However, it was gradually discontinued, culminating in the biggest industrial dispute in recent British history, between the government and the National Union of Mineworkers (NUM), the year-long miner's strike of 1984-85. Thatcher used the opportunity to oppose labour unions, which witnessed the wane of their hard-fought political power.

James Vernon (2017) argues that such a stance on unions was "essential to the deregulation of the labour market" (486). That meant giving companies more freedom on what to demand from their workers, thus, putting employees in a position in which they would have to do more without necessarily being paid better wages. The government expected to attract multinational companies, as deregulation would make it easier to cut costs. The change was so comprehensive that even the few services that were kept State-sponsored, like basic education and health, suddenly found themselves having to abide by new managerial rules typical of the corporate world (Vernon 488).

The period is thus marked by a shift from the notion of a welfare state provided by the government to individual agency and entrepreneurship. This is epitomised in one of Thatcher's most famous quotes: "there's no such thing as society. There are individual men and women and there are families. And no government can do anything except through people, and people must look after themselves first" (qtd. in "Margaret Thatcher: a life in quotes," 2013). The common citizen could not expect to be helped by the State any longer. Many British fiction writers have represented such context as the beginning of the end of the welfare state in Britain.

This period has become even more complex with the advent of globalisation. Not only have workers had to rely less on the State, but they actually have fewer opportunities of labour. Automation and outsourcing of production to countries where the workforce is considerably cheaper have rendered many occupations virtually extinct in developed countries. In Britain, for instance, many industries have been transferred to Asian countries which were part of the former British Empire (Vernon 487-8). 
This shift from an industrial country that provided job security and welfare to its citizens to a post-industrial country with fewer jobs and scarce possibilities of relying on state benefits is what we focus on when discussing Irvine Welsh's work. We offer, thus, a brief overview of the writer and his works in the next section.

\section{Irvine Welsh and his fiction}

Irvine Welsh belongs to a relatively new generation of Scottish fiction writers who approach matters related to national identity and language, social criticism and literary tradition, amongst other topics. Novelists such as James Kelman, Alasdair Gray, and Alan Warner, to name but a few, are part of such generation, which problematises the fact that Scotland is still a nation under the rule of a conservative government centred in the alien city of London. As David Leishman (2006) argues,

The socio-political context remains ever important in a Scottish literature which shows itself, by its recurring thematic concerns - linguistic oppression, constitutional dissatisfaction, the destabilising effects of rapid deindustrialisation, the alienation that accompanies modern capitalism to be painfully aware of the context of its production. (124)

Their narratives gravitate towards the working classes in Scotland, as they focus on the negative consequences the proletariat has had to endure due to British policies. This is the reason why Scottish contemporary fiction seems to have drawn closely on a sort of gritty realism that depicts a context of squalor in urban areas (Leishman 124).

One of the most important topics approached by these authors is the notion of a national identity. Despite belonging to the UK, Scotland may be thought of as an English colony, an aspect which could arguably be used to defend that their literature fits the umbrella term post-colonial literature. As Scotland lacked its own Parliament for almost three hundred years, the policies dictated by Westminster did not hold the interests of Scots at heart. If one conceives of politics, culture and identity as interwoven, there is no possibility of understanding Scotland without approaching it as a nation under the throne of England, and, therefore, as having an ambiguous national identity, to say the least.

Such ambiguity is repeatedly presented by Welsh in his novels. Besides, he raises questions pertaining to late-stage capitalism and neoliberalism, especially their noxious effects to the working classes of his hometown. In many novels, Welsh shows the harsh realities of marginalised members of Scottish society in a post-industrial world. His stories deal with topics such as drug abuse, alcoholism, crime, child abandonment, poverty, State abandon as well as State authoritarianism, amongst others. Welsh's outlook is caustic and critical, his discourse rather acid, as he lays bare some of the evils of contemporary Western capitalist society.

The characters he creates are common citizens, who have either worked in factories or in the services industries. Most are unemployed, living on benefits or on odd jobs. Others resort to illegal activities and elaborate schemes. Scheme is 
a crucial word in Welsh's fiction: most of his characters are "schemies", i.e. people who come from housing schemes provided by the government to the poor. "Schemie" carries, hence, a double meaning: not only does it refer to people who come from poverty-ridden areas, but also to someone who lives off schemes.

Welsh's schemies are mostly from Leith, a traditional working-class district in Edinburgh that pervades the universe of his oeuvre. Ten of his twelve novels present characters who are from such neighbourhood. One may have the impression that Welsh has actually been collecting chronicles of Leith. This should not come as a surprise, as the author is closely associated with the district.

He was born in Edinburgh, Scotland, in 1961, and was raised in Muirhouse, a housing scheme similar to the ones he regularly visited in Leith. As a young man, he worked in the service industry in his hometown, moving to London, at the end of the 1970's, to join the ebullient punk rock scene. After getting involved in the underworld of crime, which made him spend some time in prison, he started working at the property market in London, which became increasingly lucrative in the 1980's. Having become somewhat affluent compared to his previous condition, he returned to his native Edinburgh, where he found work in the housing department of the City Council. He was again in touch with the ethos of the housing schemes.

In the early 1990's, motivated by rave culture and the development of new literature in Scotland, Welsh decided to use some material from old journals he kept to try his hand at writing fiction. He soon published some short stories. The magazines in which he published his material openly aimed at presenting literature that tackled real and quotidian Scotland, focusing on urban realities rather than the traditional clichéd image of the Scottish Highlander. They also planned to present stories that would be different from the mainstream upper-class literature published in London. In 1993, Welsh's debut novel, Trainspotting, was released. It sold beyond reasonable expectations, becoming a financial success. After being adapted for the big screen in 1996, Welsh became a worldwide hit. Thus, the counsellor for the housing department of Edinburgh could leave his day job and become a full-time writer.

As mentioned above, his stories and novels deal constantly with Leith and its inhabitants, the Leithers. He approaches their way of thinking and acting, their working-class ethos. Welsh does that showing every aspect of their culture, without hiding its ugly face. While it is true that his schemies have been constantly wronged by the rich and powerful, they are not presented as having superior characteristics or morals to the elites. His Leithers are misogynist, racist, sexist, crude, violent and cruel, as much as the government that has abandoned them.

This is not only shown in the characters' traits and doings but even in their own language. Welsh does not write using standard English spelling, as he tries to represent the speech of the working classes of Edinburgh. He does not write in Scots, or at least not in its literary or traditional version, but in what John Skinner (1999) has defined as "metropolitan Scots" (218). He transcribes the way each character speaks, using slang, rhyming-slang and many expletives. By doing so, 
Welsh does not romanticise the working class, but shows it in its stark and gritty reality (Morace Welsh's Trainspotting 2001, 26).

As mentioned before, his oeuvre is concerned with the transition from an industrialised to a post-industrial Scotland, where there are fewer and fewer opportunities for those of humble origin to ascend or even to earn a decent living. We understand that he basically shows three possible destinies for the workers he depicts: (1) they fail to adapt to the new realities imposed, succumbing to redundancy; (2) they adapt to neoliberal practices of entrepreneurship but are, nevertheless, exploited by the rich; or (3) they continue to thrive in illegal activities, adapting neoliberal practices to their schemes. The three possibilities entail the end of working-class solidarity, as the characters must think of their own needs. This period of transition and such consequences are, in our view, particularly well depicted in the corpus we have selected. Hence, we proceed to its analysis in the next section.

\section{Corpus}

As aforementioned, the characters of two apparent universes - that of the Trainspotting Saga and that of Glue - actually belong to one and the same: Leith and its schemes. Considering that, we approach the selected novels as pertaining to the same unit. Our discussion obeys a thematic configuration, which makes us come and go from one novel to another, in a fragmentary but not disorderly way.

Glue (2001), Welsh's fourth novel, was published after he had already become a worldwide literary phenomenon. It tells the story of four friends from Leith, who go through several experiences together, from their formative years at school up to their late thirties. They are Carl Ewart (The Milky Bar Kid), Billy Birrell (Business Birrell), Terence Henry Lawson (Juice Terry), and Andrew Galloway (Gally). The title of the novel does not refer to substance abuse, a common motif in Welsh's oeuvre, but to the idea that friendship is what keeps these characters together. Morace has noted that the epigraph to the novel, a dictionary entry that reads "glue: gloo, n. an impure gelatine got by boiling animal refuse, used as an adhesive", works as a paratext that "points to the characters' status as schemies (animal refuse) in the eyes of mainstream middle-class society" (Irvine Welsh 143). We would add to Morace's considerations by arguing that the adhesive quality of glue might suggest that the refuse it is made of is ingrained in the characters, i.e. their status as irrelevant people is almost permanent. This is, indeed, a dominant feature in Welsh's books that deal with Leithers, as they are usually presented as marginalised members of society.

Due to its structure and clear timeframe, Glue might be considered Welsh's most exemplary novel in which the notion of transition is at the core of discussion. It is divided in four sections, each being related to a decade: 1970's, 1980's, 1990's, and 2000's, which are, then, followed by an epilogue.

Sections 1, 2 and 3 are subdivided into five headings. They start with "Windows '70", "Windows ' 80 " and "Windows '90" respectively, which are narrated in 
the third person. Such introductory headings are followed by others with the names of the four characters, which are, in turn, subdivided into chapters. The chapters are always narrated by the character to whom they are linked, bringing a polyphony to the narrative, a technique first used by Welsh in Trainspotting (1993). The last section is different. Although it starts with "Windows '00", it presents headings that point to the locations where Terry, Billy, and Carl, the three remaining characters, are at the moment of the story, making the narrative more fragmented and, therefore, more complex.

The first section is rather short, as it gives us the background of each character, introducing them in their childhood. Despite coming from the same district, they have somewhat different origins. Carl and Billy, for instance, come from well-structured families, in the traditional sense, whereas Terry and Gally have absentee fathers. Terry's father is the typical womaniser who ends up with more than one family, not catering for the needs of any of them. Gally's is involved in the underworld of crime, which makes him run away from Edinburgh, therefore leaving his family.

The first section is rather important for our discussion due to two aspects. First, the heading "Windows "70" refers to the time when the City Council finished building and delivered new housing schemes for the population of Leith. It shows the Galloway family moving into their new home, full of hopes and dreams of a better life:

Davie [Gally's father] felt like a newly crowned emperor surveying his fiefdom. The new buildings were impressive all right: they fairly gleamed when the light hit those sparkling wee stanes embedded in the cladding. Bright, clean, airy and warm, that was what was needed. He remembered the chilly, dark tenement in Gorgie; covered with soot and grime for generations when the city had earned its 'Auld Reekie' nickname. Outside, their dull, narrow streets nipping with people pinched and shuffling from the marrow-biting winter cold, and that rank smell of hops from the brewery wafting in when you opened the window, always causing him to retch if he'd overdone it in the pub the previous night. All that had gone, and about time too. This was the way to live! (Glue 3)

In spite of the warmth of his new surroundings and the hopeful feeling they stir, Davie shows he is incredulous of its lasting, when he says to himself “-Naw, take it while ye can get it. This is Scotland, mind, it's no gaunny last" (4). It foreshadows the fact that such schemes would later become an utter failure at addressing the social issues the working class went through during the 1980's in Leith. The new buildings would become sites for illegal activities, such as drug trafficking and prostitution.

The second important aspect in the first section is what we have argued to have been gradually destroyed during the Thatcher years, i.e. working-class solidarity. The heading dedicated to Carl Ewart in the first section does not precisely focus on him, but on his father, Duncan Ewart, and the influence he exerts on the factory where he works. Portrayed as a hardworking man who 
shows an utter disregard for authoritarian attitudes, Duncan symbolises the traditional ideals of trade unionism. The chapter depicts him during a typical day at work, when a colleague, Billy Birrell's father, reaches him for help. Wullie Birrell is worried because his wife has gone to hospital, as she is in labour, about to give birth to Billy's brother. However, their supervisor, Abercrombie, does not allow Wullie to accompany his wife, threatening to make him redundant if he leaves the grounds of the factory. Duncan calmly tells Wullie to go, calls some superiors at the factory and files a formal grievance with the manager, Mr. Catter, who knew well that Ewart "could get every man on the shop floor to walk off the job in support of this Birrell fellow" (20). After getting his point across to Catter, and sensing that he has won the battle, Duncan takes the opportunity to ridicule Abercrombie:

On his way back to the machine shop, Duncan Ewart couldn't resist poking his head into the pen, boxed off from the factory floor, which Abercrombie called his office. -Thanks, Tam!

Abercrombie looked up at him from the grease-paper worksheets sprawled across the desk. -What for? he asked, trying to feign surprise, but his face reddened. He'd been harassed, under pressure, and hadn't been thinking straight about Birrell. And hed played right into that Bolshie cunt Ewart's hands.

Duncan Ewart smiled gravely. -For trying to keep Wullie Birrell on the job on a Friday afternoon with the boys all itching tae down tools. A great piece of management. I've put it right for ye, I've just told him to go, he added smugly.

A pellet of hate exploded in Abercrombie's chest, spreading to the extremities of his fingers and toes. He began to flush and shake. He couldn't help it. That bastard Ewart: who the fuck did he think he was? -Ah run this fuckin shop floor! You bloody well mind that!

Duncan grinned in the face of Abercrombie's outburst. -Sorry, Tam, the cavalry's on its way.

Abercrombie wilted at that moment, not at Duncan's words but at the sight of a stonyfaced Catter appearing behind him, as if on cue. Worse still, he came into the small box with Convenor Bobby Affleck. Affleck was a squat bull of a man who had a bearing of intimidating ferocity when even mildly irritated. But now, Abercrombie could instantly tell, the Convenor was in a state of incandescent rage.

Duncan smiled at Abercrombie and winked at Affleck before leaving and closing the door behind them. The thin plywood door proved little barrier to the sound of Affleck's fury.

Miraculously, every lathe and drill machine on the shop floor was switched off, one by one, replaced by the sound of laughter, which spilled like a rush of spring colouring across the painted grey concrete factory floor. (Glue 20-21)

The last paragraph of the passage above clearly evidences the positive feeling of solidarity, strength and union the workers share when they see their colleague has been vindicated. However, one has to remember that this scene happens in the 1970's, before Thatcher becomes Prime Minister and starts hampering the influence of unions all over the UK. One of the most striking passages in Welsh's 
oeuvre related to how unions were dismantled is found in Skagboys (2012). Written as a prequel to Trainspotting (1993), the novel centres on another group of schemies from Leith who are well-known to the Welsh reader, as they had appeared in his debut novel and its sequel, Porno (2002). The four main characters, younger than those in Glue, are Mark Renton (Rents), Simon David Williamson (Sick Boy), Francis Begbie (Generalísimo Franco), and Daniel Murphy (Spud).

Skagboys opens with diary notes written by Renton during a rehabilitation programme, recalling his participation in one of the most important historical events of the 1980's concerning the working classes of Britain: the Battle of Orgreave. It happened on 18 June 1984, in Yorkshire, during the miner's strike. Previously, the police would protect factories and workers who did not join strikes from picket lines. However, in Orgreave, they charged against the demonstrators, causing violence and chaos in an unprecedented scale up to that point. With 123 people injured and 91 arrested, the aftermath of the event changed many practices in unions and demonstrations in the UK. Thatcher seized the opportunity and used it to ban picket lines and secondary action after that (Vernon 498-9).

The diary entry shows Renton detailing the mayhem as he not only witnesses but takes part in it. He first describes the atmosphere in the bus that took him and his father (a member of a union showing solidarity to the plea of the miners) to the picket line as rather positive, as if the strikers were heading to a football match, all celebrating a possible victorious outcome together. Their spirits are further lifted by Arthur Scargill (then president of the NUM), when he inflames the strikers with his powerful speech:

Scargill's got the megaphone and he launches intae one ay his trademark rousin speeches that tingles the back ay ma neck. He talks aboot the rights ay working people, won through years of struggle, and how if we're denied the right to strike and organise, then were really nae better than slaves. His words are like a drug, ye feel them coursin through the bodies aroond ye; moistening eyes, stiffening spines and fortifying hearts. As he wraps up, fist punched into the air, the 'Victory to the Miners' chant reaches fever pitch. (Skagboys 12-3)

However, the demonstrators soon find themselves in the midst of chaos, as the police attack the picket line. 'Them fookin small shields, another gadgie shouts, 'they're for aggro, not fookin defendin their sen!"' (Skagboys 14). The police charge on horseback, forcing the strikers to retreat and causing a massacre. Renton is hit on his back, arm and temple, but is still able to escape worse injuries, which is not the reality for many of the workers assembled:

Ah see one boy's doon and getting battered tae fuck by three polis. They're bendin over him, thrashing at him with their sticks. A lassie, about ages wi me, long, black hair, is screaming at them in appeal: 'What are you doing!' One of the cops calls her a miner's slag and pushes her. She stumbles and faws oan her back, $\mathrm{n}$ gits pilled away by this aulder boy, who takes a stick acroas the shoulder for his trouble. Every cunt's screamin and shoutin $n$ 
ah'm standin, paralysed between thought and action, just jammed, and an aulder copper looks at me, glances at the younger polis, then barks right in ma face, 'GET THE FUCK OUTTA HERE NOW, OR YOU'LL GET FUCKIN KILLED!' (Skagboys 15)

The action ensues, with the police beating the strikers, making them run for their lives, as they realise "these cunts really want us deid" (Skagboys 17) and that "a war against civilians" (Skagboys 18) has just begun. Renton concludes that such carnage will now be part of official policy, as he ponders that "[a]nti-union laws and big pay rises for the polis when everybody else in the public sector's dosh and conditions are getting cut back... the cunts fuckin primed them for this..." (Skagboys 19). Thatcher has, hence, started the process of dismantling unionism and what it represented for so many years in Britain.

The diary entry finishes with Renton desperate, seeing that the workers have taken their final blow and that life in the UK, especially for a young man like himself, has been changed forever: "Ah'm thinkin that we've lost, and there's bleak times ahead, and ah'm wonderin: what the fuck am ah gaunny dae wi the rest ay ma life?" (Skagboys 21).

This is the turning point for Renton and everything that happens to him and his friends later on. Although Renton seems to be the one whose hopes are the brightest compared to his friends', as he is the only one who is able to progress to higher education in a university, he chooses to abandon every expectation and surrender to skag, i.e. heroin. At last, he introduces the narcotic to his mates Sick Boy and Spud. They start, then, resorting to illegal activities in order to pay for their addiction. Renton and Sick Boy eventually find work in ferries that go to Amsterdam, where they can procure heroin more easily. They are involved in a scam that uses the ferries to smuggle the drug into the UK.

Although this part of the novel focuses on their frantic chase of heroin, the changes effected by Thatcherism at the workplace as well as how the government dealt with unemployment figures are exposed in many instances. First, there are very small chapters throughout the novel entitled "Notes on an Epidemic," which address, amongst other things, the rise in cases of AIDS in Edinburgh. Such chapters work as historical notes that lay bare the context of want faced by the working classes during the 1980's. The second of such notes show how numbers were manipulated for the sake of protecting the policies introduced by the State:

government statistics became more politicised than ever before; twentynine changes in the way unemployment figures were calculated effectively made the real total impossible to determine. Hundreds of thousands of people were removed from the unemployment register by making it progressively harder for people to obtain benefit, then counting only those who were in receipt of benefits, rather than claimants, as genuinely unemployed. (Skagboys 139)

Not only is the welfare state being hampered, with figures being manipulated, but also the regulation of working conditions becomes increasingly lax. As 
unions gradually lost power, many workers had to accept new contracts and conditions. If they did not comply, they could lose jobs and probably fail to collect unemployment benefits. This is clearly denounced when Sick Boy and Renton start work at the ferries. They are supposed to work as stewards, but are hired as operatives, when we learn that in "the post-privatised, non-union epoch, they are all referred to in this way rather than 'stewards'. Operatives are paid less" (Skagboys 324).

One of the ferries where they work is ironically named The Freedom of Choice. According to Renton, this is the weirdest place he has ever worked, as no one does anything properly. He explains that every member of the crew is actually an expert at "avoiding work; no just the seasonals, but the established staff tae. They've aw been issued new contracts ay employment, which means longer hours fir far less pay, so motivation is non-existent" (Skagboys 348).

Owing to such dire prospects, some characters of the selected novels get involved in criminal activities. In Glue, they get associated with local thugs. Gally is the one who is truly affected by his circumstances and the underworld of crime. Despite being the most caring and gentle character, he gets involved in illegal activities, and, like his father, ends up in prison. First, he takes the blame for a felony he does not commit, as he sticks to the working-class code of behaviour, which says you should never turn anyone in. This sends him to a youth detention centre. After he is released, he falls under the dynamic of ex-convicts, living off illegal deeds, eventually being taken and sentenced to jail. This causes Gally to become ill with depression. Like the core group of the Trainspotting saga, he starts using heroin to deal with his mounting problems, only to discover he has become HIV positive due to sharing needles. In a very compelling scene, he commits suicide jumping from George IV Bridge in Edinburgh. This is a stark contrast from his prospects described in the opening pages of the book, when his family enters the new flat offered by the council. As his father says, good things cannot last in Scotland.

In Skagboys and Trainspotting, illegality becomes the order of the day. Renton, Sick Boy, and Spud use different scams to get unemployment benefits. They also commit petty crimes, such as shoplifting and burglaries. The original novel of the series basically focuses on plans they carry out so that they can have enough money to pay for their heroin addiction. The only character who does not fall under the spell of such a narcotic is Francis Begbie. Nonetheless, he becomes the local thug. Generalísimo Franco, a nickname he gets as he becomes increasingly more fearsome (just like the Spanish dictator), rises in the criminal ranks in Leith, making a reputation as a formidable mobster. His fate cannot be another but prison. He is eventually incarcerated for murder.

However, most characters do succeed in adapting to the new circumstances dictated by Thatcherism. At the end of Trainspotting, the core group of four friends, along with Rab McLaughlin, get involved in a heroin deal with a drug trafficker in London, bringing them a rather positive financial gain. The language used to describe the scam is rather interesting, as it carries undertones of neoliberal thinking: 
Gilbert was a professional who had worked in drug-dealing for a long time. He'd buy and sell anything. For him, it was strictly business, and he refused to differentiate it from any other entrepreneurial activity. State intervention in the form of police and courts merely constituted another business risk. (...) Gilbert was, by nature of his contacts and his venture capital, able to procure drugs, hold them, cut them and sell them to smaller distributors. (Trainspotting 339)

Gilbert, the drug dealer, symbolises the other side of the neoliberal coin: an entrepreneur who has venture capital and expertise, who takes risks and makes money change hands, albeit providing illegal services for eager and faithful clients who constitute a specific market. Drug dealing is constantly presented by Welsh as the logical extrapolation of neoliberal practices, and the dealer as the embodiment of the capitalist entrepreneur.

It is no surprise, then, when Renton decides to take the same route and think of himself first, as a true neoliberal, when faced with an opportunity. Feeling that he needs to leave Leith and Scotland altogether so that he can pursue some sort of decent existence, he betrays his friends and escapes to Amsterdam with the full amount of money, leaving them penniless. Bearing in mind that "there is no such thing as society," Renton proves he can take care of himself without resorting to the State, showing the spirit of entrepreneurship by taking advantage of the situation in his biggest scam up to that point.

Porno, sequel to Trainspotting, further problematises the consequences of neoliberal politics. Set in the beginning of the new millennium, the novel brings characters from the two groups of friends coming together. Sick Boy, in a major scam that parodies the notion of entrepreneurship, decides to enter the world of adult entertainment. Having been granted the chance to run a pub in Leith, he uses it as a setting where he can shoot pornographic films, albeit illegally. Terry, from Glue, a sex addict, joins Sick Boy's team as the main actor. If sex has become a product to be consumed in the new social order, Sick Boy certainly wants his share of the profits. As he himself says:

(...) we need tits and arse because they have got to be available to us; to be pawed, fucked, wanked over. Because we're men? No. Because we're consumers. Because those are things we like, things we intrinsically feel or have been conned into believing will give us value, release, satisfaction. (...) For tits and arse read coke, crisps, speedboats, cars, houses, computers, designer labels, replica shirts. That's why advertising and pornography are similar; they sell the illusion of availability and the non-consequence of consumption. (Porno 450)

By using the motif of pornography, Welsh lays bare how the commodification of practically every aspect of the human experience and psyche along with the deification of the idea of a free market - assumptions that can be said to be at the core of neoliberal thinking and practice - are dangerous both to the individual and society. If we become nothing but consumers, everything must be saleable and readily available, or, at least, theoretically available. We cease to be 
individuals working for the benefit of a community and become merely neverending consuming machines, who will provide entrepreneurs with profits.

The Blade Artist takes a stance on the culture of celebrity and the commodification of art and violence. It presents the former thug and convict Begbie reinventing himself as Jim Francis, a successful artist. Now an expatriate, living in California, he sublimates his violent impulses in paintings and sculptures, some of which depict famous celebrities being mutilated. This generates a new artistic trend, which Begbie himself ridicules. He reads a review of his art to a friend and then comments on it:

His striking portraits and sculptures of Hollywood and British television stars, complete with vicious mutilations, taps into our subconscious desire as a public to build up and then destroy the celebrity...

(...) -It starts that Schadenfreude art movement, he says, a sour contempt creeping into his tone. -Bring me your celebs. I'll hurt them, age them, degrade them, envision their first child being delivered by Fred and Rosemary West. Etch the pain on their pretty faces. Show everybody that they're just like us.

(...) -My talent was for hurting people. That's what I was venting, the desire to hurt another human being. (...) -Society is fucked. I just give messed-up people what they want. (The Blade Artist 82-3)

Not only does Welsh criticise the culture of personality, he also shows that, under late capitalism, practically anything can be turned into a product to be sold and generate profit, even violence. The reviewers' spurious explanations on why Begbie's art attracts such a big audience work as a discourse not only to appease feelings of shame for desiring the demise of others but also as an invitation for the consumer to indulge in such destructive pleasures. In the name of a free market, instead of seeking the common good or improving the mental health of the populace in general by avoiding negative moods, those who work in the fields of the arts comply with the dictates of neoliberal thought, by commodifying hatred.

Dead Men's Trousers, the final novel of the saga so far, lays bare what happens to these characters who have gone through this period of continuous transition. Sick Boy has finally become the entrepreneur he has always fancied himself to be. He runs an escort company, using his experience as a pimp from his younger days. If Thatcher envisioned a world with practically no State regulation, Sick Boy gives his clients freedom to choose with whom to have sex, as long as you pay for that. His attitude epitomises neoliberal entrepreneurship, as he is always ready to adapt and make the most of each opportunity, turning the consumer's appetites and weaknesses into assets for his company.

Begbie has become famous with his art. He returns for his first exhibition in Edinburgh, meets his former friends, and makes peace with them all. For the first time, he sells one of his works reaching the figure of a million. He is unfazed, as he knows other people will make more money than him from his own work. When his agent tells him the news, he replies, "[g]allery gets half, so that's half a mil. 
You get a hundred grand, that's four hundred thou. Taxman gets a hundred and fifty, that's a quarter ay a million bucks" (Dead Men's Trousers 310). His financial means may have improved dramatically, but he realises that the workers of the world of entertainment, so central to late stage capitalism, are exploited as much as traditional working classes. Inasmuch as the cultural market has boomed in the West, it is deployed in such a way that the rich can make more money with the work of upcoming artists.

Renton also belongs to the world of entertainment, as he manages DJs. In the last novel, he is rather unhappy with his life, tired of dealing with constant trips and negotiations, of having to cope with all the absurd demands and psychological needs of the artists he manages. Once again, we are given the impression that neoliberal policies of deregulation made it possible for workers to be further exploited. Renton is no exception. In a certain point of the novel, we see the hard time he goes through to get the specific kind of equipment one of his DJs demands, just because he refuses to play with more modern systems, favouring vintage ones.

The artist that annoys Renton is N-Sign, artistic name for Carl Ewart, originally from Glue. In spite of Gally's suicide, a fact that inflicts a schism in the group of friends, forcing each of the remaining three to find their own way, Glue finishes in a relatively positive tone. Carl becomes a successful DJ, but has to numb the pain he feels from the trauma of seeing his friend killing himself by taking drugs. Like Begbie and Renton, he works in the world of entertainment, and has to face an ever-increasing need of the market for novelty. He reappears in Dead Men's Trousers as someone who was once a pioneer of electronic music, but has somewhat faded from the public eye. He needs to make an effort so that he can live off his music again. While it is true that the culture market has become one of the most lucrative industries in the West, it does not mean that the people who are involved in its creative processes become as rich as the investors. Just like Begbie, Carl may have reached a much better condition than he had in Leith, but he is still a pawn making the rich richer.

Billy is the most rational and circumspect of the four friends from Glue. He becomes a sportsman and has a short but successful career as a boxer. He ends up managing a bar, though, which belongs to shady gangsters from Edinburgh, who choose Billy as its manager due to his popularity. Although it may seem Billy has become the most fortunate of the group, his accomplishments are sullied - one has the impression the bar he manages is used to launder money of the owners.

Terry, on the other hand, cannot escape the limitations his environment imposes. He becomes a taxi driver, making extra money selling drugs to willing passengers. He is not an ambitious man. Having money to eat and plenty of sex is enough for him. Unable to escape his origins, Terry symbolises the worker who has been abandoned by a State that wants him to believe he can be content with basics, without aspiring for more.

He is similar to Spud, who also has no ambition whatsoever. Spud just wants a life of peace with his basic necessities met. But society and the State fail at 
giving him that little portion of contentment he seeks. Unlike Terry, Spud cannot find another job after he is sacked. He spends most of his existence resorting to ill-planned scams and using his unemployment benefits to obliterate his pain through heroin. He is the only one who cannot overcome his addiction, perhaps because he cannot overcome reality. He finally gets involved in a dangerous scheme, which eventually kills him. His son, Andrew Murphy, gives the reader a moving speech during his funeral:

-My dad worked in furniture removals. He liked that manual labour, loved the optimism people felt when they were moving into a new home. As a young man, he was made redundant. A whole generation were, when they shed all the manual jobs. Dad wasn't an ambitious man, but in his own way he was a good one, loyal and kind to his friends. (...) - My dad wanted to work. But he had no skills or qualifications. It was important to him that I got an education. I did. Now I'm a lawyer. (...) And in a few years, maybe five, maybe ten, I'll be as redundant as he ever was. The lawyer will be gone, like the labourer before him. Made obsolete by big data and artificial intelligence. What will I do? Well, then I'll find out just how much like him I am. And what will I say to my child, he points to his girlfriend, her belly swollen, -in twenty years' time, when there are no labourers' or lawyers' jobs? Do we have a game plan for all this, other than wrecking our planet in order to give away all its wealth to the super-rich? My father's life was wasted, and yes, a lot of it was his own fault. Still more of it was the fault of the system weve created. (...) -What is the measure of a life? Is it how much they've loved and been loved? The good deeds they've done? The great art they've produced? Or is it the money they've made or stolen or accumulated? The power they've exerted over others? The lives they've negatively impacted upon, cut short or even taken?" (Dead Men's Trousers 348-349)

The passage above is exemplary for our discussion in many ways. Firstly, it refers to a character who worked in the removal industry. Spud witnessed families who were going through periods of transition in their lives. The optimistic feeling of seeing such families entering new homes, full of hopes and dreams for a bright future, just like Gally's father in the opening pages of Glue, is in stark contrast to the transformation he had to experience as a worker. Spud stands as the ultimate representation of the ills manual labourers in Britain had to accept as part of their new reality. He may be said to symbolise the common worker in its final defeat. Secondly, Andrew Murphy's words lay bare the fact that the ever-changing free market imposes contexts with which the working class is unable to deal. His prospects, as well as those of his still unborn son, are dire. There seems to be less and less the common citizen can do to oppose policies which favour financial gains for the rich over the well-being of the populace. Finally, his questions at the end of the quote appear to be a warning, in order to raise our awareness that we ought to do something to change this trend, initiated with the neoliberal twist in the 1970's and which is still on its tracks today. The market, with its supposed impersonality and its need to keep the wheels of the economy turning non-stop, may effect the final blow on humanity as a whole. If nothing is done, life may 
become redundant in the name of profit. Thatcher's words might prove truer than expected, as there might be no such thing as society in the future.

\section{Final Considerations}

We have argued that Welsh presents a generation whose origins lie in an industrial economy having to grapple with the changes effected by Thatcherism and trying to adapt to the new context of a post-industrial world, in which the State plays a minor role when it comes to regulations and providing the populace with welfare ${ }^{1}$. We have demonstrated that some of the characters (1) have failed to adapt to their new circumstances; (2) have succeeded in adapting to practices of entrepreneurship only to be further exploited by the rich; or (3) have adapted such practices to illegal activities. In the first instance, Gally's suicide and Spud's death point to the failure of both characters in dealing with such a period of change. It also lays bare the decline of the welfare state in Britain and the inability of the State to plan for the well-being of its citizens. In the second instance, characters such as Begbie, Renton, and Carl, who work in the fields of entertainment and the arts, seem to have adapted to the market demands of the new world. However, although their jobs allow them to have somewhat reasonable lives, lax regulations create the conditions for them to be exploited, as they generate more money for others than for themselves. In the third instance, Terry, Sick Boy, and Billy are depicted as characters who can adapt, but who continue depending on the underworld of crime. Billy's pub is probably used for laundering money. Terry uses the idea of entrepreneurship to sell drugs to passengers of his taxi. Sick Boy, an egomaniac, is a parodic extrapolation of neoliberal thinking, as he uses its practices in never-ending scams. All such instances point to the fact that the sense of community and solidarity typical of the working classes, that existed before Thatcherism, has been terminated. As Hugo Young (2013), biographer of Thatcher, puts it, one of the dire consequences of her policies was that "the sense of community evaporated. There turned out to be no such thing as society".

The novels we have analysed are deeply rooted in their social and historical background. We believe literature can help us understand more thoroughly how historical events and trends affect the daily lives of the common citizen, as it can personalise historical or social experiences. Having said that, Welsh's novels stand as cultural artefacts of ultimate importance for people who wish to grasp the changes neoliberal policies have effected and/or may still effect on their lives. We still see many places in the world where governments have been acting in the interests of the elites, disregarding the common good, always in the name of the economy and big businesses. If Irvine Welsh, who writes so vividly about the experience of squalor by the working classes in Scotland, is warning us concerning what we may face in our future, we had better heed him. 
Note

1. This text is part of a post-doctoral research supervised by Prof. Ana Lucia de Souza Henriques, a member of the Letras collegiate of UERJ. The research focusses on representations of violence, either concrete or symbolic, in Irvine Welsh's novels. During the course of our studies, we have come to the conclusion that the notion of transition in an increasingly more capitalistic and neoliberal world is one of the major themes Welsh develops in his oeuvre. Due to the limitations of space of this article, we could only cover some of the issues concerning neoliberal practices as represented in the selected novels. We acknowledge there is much more to be covered regarding the topic of transition, both in Welsh's fiction and in historical and sociological texts which discuss neoliberalism and its effects on society. It is our intention to pursue such studies, so that we can understand the phenomenon of neoliberalism more thoroughly as well as how it is approached by Welsh, once the present research is finalised.

\section{References}

Clarke, Peter. Hope and Glory: Britain 1900-2000. Penguin Books, 2004.

Harvey, David. A Brief History of Neoliberalism. Kindle ed., Oxford University Press, 2007.

Leishman, David. “A Parliament of Novels: the Politics of Scottish Fiction 1979-1999." Revue Française de Civilisation Britannique, vol. 14, no. 1, 2006, pp. 123-36.

Morace, Robert. Welsh's Trainspotting. Continuum, 2001.

Irvine Welsh (New British Fiction). Palgrave MacMillan, 2007.

Skinner, John. "Contemporary Scottish Novelists and the Stepmother Tongue". English Literature and Other Languages, edited by Ton Hoenselaars and Marius Buning, Rodopi, 1999, pp. 211-220.

Thatcher, Margaret. "Margaret Thatcher: a life in quotes". The Guardian, 8 April 2013, theguardian.com/politics/2013/apr/08/margaret-thatcher-quotes. Accessed 21 May 2020.

Vernon, James. Modern Britain: 1750 to the Present. Cambridge UP, 2017.

Welsh, Irvine. Trainspotting. Secker and Warburg, 1993.

. Glue. London: Vintage, 2002.

. The Blade Artist. Jonathan Cape, 2016.

Porno. Jonathan Cape, 2002.

Skagboys. Jonathan Cape, 2012.

Dead Men's Trousers. Jonathan Cape, 2018.

Young, Hugo. "Margaret Thatcher left a dark legacy that has still not disappeared." The Guardian, 8 April 2013, theguardian.com/politics/2013/apr/08/margaretthatcher-hugo-young. Accessed 30 May 2020.

Recebido em: 10/06/2020

Aceito em: 28/10/2020 